Original Research Paper

\title{
Gathering Nutritious Edible Wild Plants Based on Societies Indigenous Knowledge from Sempolan, Jember Regency
}

\author{
Kuswati $^{*}$ \& Widi Cahya Adi ${ }^{2}$ \\ ${ }^{1}$ Jember University, Biology Education Study Program, Faculty of Teacher Training and Education, \\ Jember, Indonesia; \\ ${ }^{2}$ Universitas Islam Negeri Walisongo Semarang, Biology Education Study Program, Faculty of Science \\ and Technology, Semarang, Indonesia.
}

\author{
Article History \\ Received : April 19 ${ }^{\text {th }}, 2021$ \\ Revised : May 02 ${ }^{\text {th }}, 2021$ \\ Accepted : May $11^{\text {th }}, 2021$ \\ Published : May $18^{\text {th }}, 2021$ \\ *Corresponding Author: \\ Kuswati, \\ Universitas Jember, \\ Jember, Indonesia; \\ Email: kuswati.fkip@unej.ac.id
}

\begin{abstract}
Indonesia, as a mega biodiversity country, has various types of wild plants. Sempolan Village, part of Jember Regency, has fertile land to support the growth of a wild plant. This research investigates wild plants used as food sources by indigenous peoples in Plalangan, Sempolan Village. This study also conducts data on how wild plants were cooked, served, and enriched by nutrition notice. The method is qualitative descriptive analysis obtained from observation, interview, documentation, and literature study. So, research results found 26 species and grouped them into 19 families. In addition, the locality of these species is in yards, fields, and roadsides. The habitus identified is an herb (77\%), tree (11\%), shrub (8\%), and liana (4\%). Those foods categorize into 1) carbohydrates sources, 2) vegetables, and 3 ) fresh fruits. The carbohydrate sources mostly served as a side dish, compote, and flour by stewing and frying. The vegetables include 18 species served as complements of the main menu, which cooked for soup, curry, stir fry, ointment, and pothok. Fresh fruits comprise of 4 species were directly consume or make a salad. Furthermore, all food resources contain essential nutrients like vitamins, macro and micro minerals, and phytochemicals that are important for society's growth and healthy lives. Finally, Information on wild plants as a food source will increase food diversification as well as dishes.
\end{abstract}

Keywords: Wild plants, Vegetables, Fruits, Dish, Nutrition

\section{Pendahuluan}

Desa Sempolan - Kabupaten Jember, memiliki luas wilayah 683, 623 Ha terbagi menjadi 3 Dusun yaitu Plalangan, Krajan, dan Onjur. Dusun Plalangan memiliki kondisi tanah yang umumnya berupa lahan kering, terdiri atas lahan pertanian (lahan sawah dan lahan tegal), dan tanah pemukiman / pekarangan (DBpedia, 2020). Penduduk dusun Plalangan didominasi oleh masyarakat etnis madura yang dicirikan dengan penggunaan bahasa madura khas yang dikenal dengan dengan bahasa Madura Jemberan (Umiyah, 2011). Adapun mata pencaharian utama masyarakat adalah sebagai petani/ pekebun.

Lahan subur merupakan daya dukung utama media bercocok tanam. Di Dusun Plalangan, dapat dijumpai beraneka jenis tumbuhan sebagai sumber pangan, yang tumbuh sepanjang tahun maupun silih-berganti bergantung musim. Tumbuhan pangan merupakan kelompok tumbuhan yang memiliki bagian / organ yang dapat dikonsumsi baik dengan cara diolah maupun dimakan langsung (Diba et al., 2021). Handayani \& Marwanti (2011) mengelompokkan jenis olahan makanan Indonesia antara lain makanan pokok, lauk pauk, sayuran, sambal, sedap-sedapan, dan minuman. Komoditas pangan haruslah mengandung zat gizi 
yang terdiri atas karbohidrat, lemak, protein, vitamin dan mineral agar dapat memenuhi gizi harian dan menjaga kesehatan masyarakat.

Pemenuhan bahan pangan masyarakat di Dusun Plalangan tidak hanya berasal dari tanaman budidaya melainkan juga tumbuhan liar. Tumbuhan liar tumbuh secara liar pada habitat yang cocok seperti dijumpai di tanah pekarangan, di pinggir jalan, dan di sekitar tanaman budidaya sebagai gulma di areal tanah sawah. Umiyah (2011) mendokumentasikan 10 jenis tumbuhan liar (gulma) yang dijadikan bahan pangan di daerah Jember dan Di Dusun Mendiro, Jombang ditemukan 43 jenis tumbuhan liar yang digunakan sebagai sumber Pangan (Sholichah \& Alfidhdhoh, 2020). Habitus dari tumbuhan liar sebagai sumber pangan sangat bervariasi mulai dari tanaman herba (terna), perdu dan berkayu. Adapun bagian tumbuhan liar yang dapat digunakan sebagai makanan meliputi daun, batang, buah, biji, bunga serta bagian akar atau batang termodifikasi sebagai cadangan makanan atau umbi (Liza., Oramahi \& Sisillia, 2020; Pawera et al., 2020; Sembori \& Tanjung, 2009). Selain sebagai sumber pangan, tumbuhan liar diketahui memiliki banyak manfaat dan terlibat dalam beberapa aspek kehidupan masyarakat, diantaranya sebagai obat (Badrunasar \& Santoso, 2016; Destryana, 2019), pakan ternak (Nurlaha et al., 2014), bahan serat dan juga pelaksanaan acara adat tertentu (Ogle, 2001).

Pengetahuan masyarakat dalam pemanfaatan tumbuhan liar sebagai sumber makanan akan meningkatkan diversifikasi pangan untuk pemenuhan nutrisi harian masyarakat. Pawera et al., 2020 mengungkapkan bahwa tumbuhan liar sebagai sumber pangan menyediakan mikronutrisi penting (mineral, vitamin) dan fitokimia (antioksidan). Vitamin dan mineral berperan luas dalam proses metabolisme tubuh, sedangkan antioksidan penting untuk melawan radikal bebas. Kandungan nutrisi lain berupa karbohidrat dan lemak sebagai sumber energi, dan protein yang berfungsi dalam pertumbuhan dan pemeliharaan sel (Khan et al., 2017; Soetiarso, 2010). Tujuan penelitian ini adalah inventarisasi jenis-jenis tumbuhan liar yang dimanfaatkan sebagai sumber pangan oleh masyarakat di Dusun Plalangan Desa Sempolan Kecamatan Silo, mendokumentasikan informasi bagian tumbuhan liar yang dapat dimakan serta cara pengolahannya, serta memperkaya dengan informasi kandungan gizi sehingga diharapkan dapat meningkatkan daya tarik masyarakat secara luas terhadap makanan lokal. Tujuan jangka panjang adalah tercapainya ketahanan pangan dan kelestarian pengetahuan masyarakat.

\section{Bahan dan Metode}

Penelitian ini merupakan penelitian deskriptif kualitatif. Bahan atau objek dalam penelitian ini adalah jenis tumbuhan liar yang digunakan sebagai sumber pangan.

\section{Lokasi dan Waktu}

Lokasi penelitian terletak di Dusun Plalangan, Desa Sempolan Kecamatan Silo, Kabupaten Jember. Penelitian dilakukan selama satu bulan, yakni selama bulan januari tahun 2021. Kawasan Dusun Plalangan dapat dilihat pada Gambar 1.

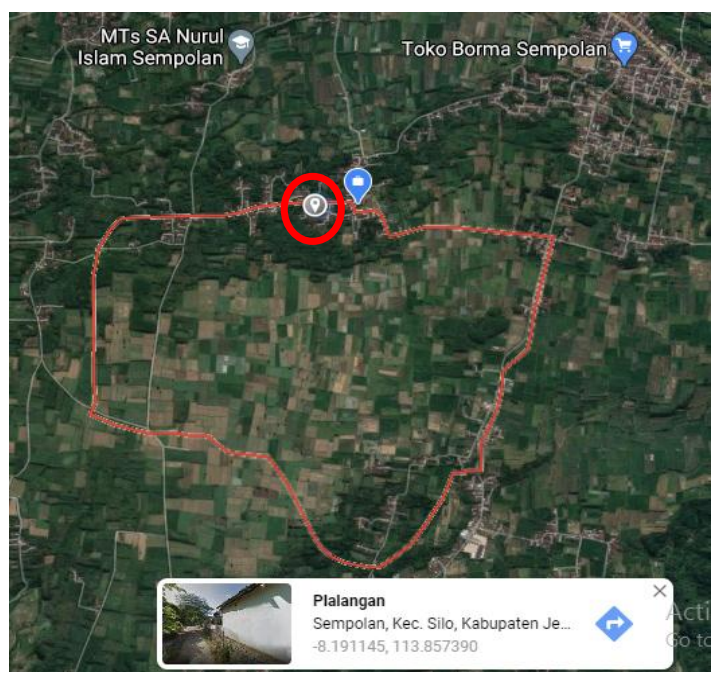

Gambar 1. Lokasi Penelitian Dusun Plalangan, Desa Sempolan Kecamatan Silo Kabupaten Jember

\section{Teknik Pemilihan Responden}

Pemilihan responden berdasarkan teknik purposive sampling yaitu pemilihan responden berdasarkan pertimbangan tertentu untuk memperoleh data yang diinginkan dalam penelitian.

Teknik Pengumpulan dan Analisis Data Jenis Tumbuhan Liar sebagai Sumber Pangan di Dusun Plalangan 
Teknik pelaksanaan penelitian ini yaitu observasi, wawancara, dokumentasi, dan studi referensi. Wawancara dilakukan Observasi dan wawancara dilaksanakan bersamaan, dengan informasi yang dikumpulkan dalam penelitian yaitu: 1) jenis tumbuhan liar yang dapat dijadikan sebagai makanan; 2) nama lokal; 3) bagian tumbuhan yang dimakan; serta 4) cara konsumsi. Dokumentasi jenis tumbuhan liar dilakukan bersama responden. Adapun responden penelitian ini adalah masyarakat etnis Madura, yang memanfaatkan tumbuhan liar di Dusun Plalangan, Desa Sempolan, Kecamatan Silo sebagai sumber pangan. Data hasil observasi, wawancara, dokumentasi selanjutnya dianalisis dengan cara melakukan pencarian informasi ilmiah dari literatur.

\section{Hasil dan Pembahasan}

Keanekaragaman Jenis Tumbuhan Liar yang digunakan sebagai bahan pangan

Berdasarkan hasil wawancara terhadap 10 orang responden didapatkan 26 jenis tumbuhan liar yang dimanfaatkan sebagai sumber makanan oleh masyarakat di Dusun Plalangan Desa Sempolan. Data tersebut disajikan pada Tabel 1. meliputi informasi spesien tumbuhan liar, bagian yang dikonsumsi serta cara pengolahannya.

Dari 26 jenis tumbuhan liar yang ditemukan, keseluruhan tersebar dalam 19 famili dimana famili terbanyak adalah dari famili Solanaceae sebanyak 23 spesies, selanjutnya famili Dioscoreaceae, Euphorbiaceae, Capparaceae, Asteraceae, masing-masing 2 spesies dan keempat belas famili lainnya hanya ditemukan masing-masing sebanyak 1 spesies.

Adapun habitus tumbuhan liar yang ditemukan, disajikan pada Gambar 2. Liana sebanyak 1 spesies (4\%) yaitu Marsdenia brunoniana; perdu sebanyak 2 spesies yaitu Euphorbia pulcherrima dan Cnidoscolus aconitifolius; pohon sebanyak 3 spesies (11\%) yaitu Morus alba, Muntingia calabura, dan Morinda citrifolia herba yaitu sebanyak 20 spesies (77\%) selain spesies yang disebutkan sebelumnya.

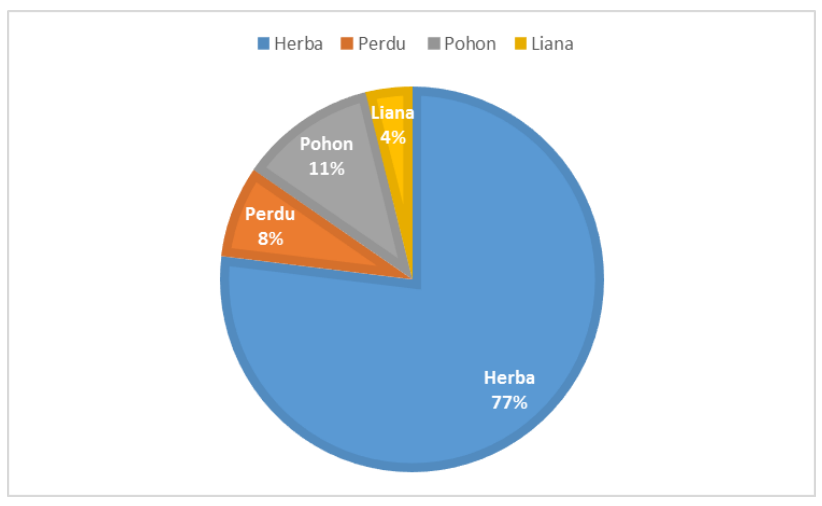

Gambar 2. Habitus tumbuhan liar

\section{Jenis Olahan dan Bagian yang dijadikan Sumber Pangan dari Tumbuhan Liar Dusun Plalangan Desa Sempolan}

Berdasarkan pemanfaatnnya sebagai suber pangan, ke 26 spesies tumbuhan liar dikelompokkan menjadi 3 kelompok yaitu 1) sumber karbohidrat; 2) sumber sayuran, dan 3) buah segar. Masyarakat Indonesia menggunakan karbohidrat dari beras sebagai sumber utama pemenuhan kalori harian. Sumber alternatif karbohidrat perlu terus digalakkan untuk memenuhi peningkatan permintaan pangan (Herison \& Turmudi, 2010). Terdapat 4 spesies tumbuhan liar yang dapat digunakan sebagai sumber karbohidrat, 2 diantaranya merupakan famili Dioscoreaceae yaitu (Dioscorea alata, Dioscorea hispida), Selanjutnya Maranta arundinacea, dan Canna edulis. Bagian tumbuhan yang dimakan oleh masyarakat adalah umbi yaitu batang/rhizoma atau akar termodifikasi sebagai penyimpan cadangan makanan. Olahan utama dari umbi-umbi tersebut sebagai makanan sampingan dengan cara direbus. Umbi Dioscore hispida dapat diolah juga sebagai keripik dan kolak sementara Maranta arundinaceae dan Canna edulis dapat dijadikan sebagai tepung dan dijadikan sebagai bahan kue (AndraFarm, 2019). Ke empat jenis umbi tersebut telah dimanfaatkan sebagai sumber karbohidrat oleh masyarakat Indonesia sejak dulu dan sangat potensial untuk dijadikan alternatif sumber karbodirat (Herison \& Turmudi, 2010; Trustinah, 2013). Masyarakat mendapatkan umbi-umbi tersebut dengan mudah karena tumbuh liar di tanah pekarangan bersama pohon-pohon dan bambu. Kandungan nutrisi 
berupa karbohidrat adalah sebagai sumber energi utama tubuh. Berpotensi komersil sebagai tanaman budidaya karena digunakan sebagai bahan baku industri kue dan dan juga pakan (Trustinah, 2013).

Kelompok yang kedua adalah tumbuhan liar yang dimanfaatkan sebagai sayur. Handayani dan Marwanti (2011) menyatakan sayur adalah hidangan berkuah berupa air/kaldu/santan dengan komponen sayuran, berfungsi sebagai pelengkap nasi. Tumbuhan liar yang dimanfaatkan sebagai sayur berkuah banyak yaitu Euphorbia pulcherrima, Amaranthus spinosus, Gynandropsis gynandra, Cleome rutidospermae, dan Marsdenia brunoniana. Euphorbia pulcherrima merupakan tanaman perdu berkayu tumbuh liar di tanah pekarangan. Daun muda dapat dimanfaatkan sebagai sayur bening, di daerah jombang dijadikan sebagai bahan makanan dan juga sayuran (Sholichah \& Alfidhdhoh, 2020). Ketiga spesies tumbuhan liar lainnya termasuk kelompok tumbuhan herba, tumbuh liar di tanah sawah kering sebagai gulma. Tumbuhan Cleome rutidospermae diolah menjadi sayuran bening maupun tumis, dari bagian daun muda dan bunga (Umiyah, 2011). Amaranthus spinosus dikenal secara luas menjadi sayuran bahwa sangat berpotensi untuk dibudidayakan (Pawera et al., 2020; Soetiarso, 2010). Gynandropsis gynandra atau Cleome gynandra digunakan sebagai sayur khususnya bagian daun dan bunga (Heuze, V., Tran G., and Lebas F: 2020). Masyarakat sempolan menyebut tanaman Gynandropsis gynandra sebagai boboan binik/wedok dan Cleome rutidospermae sebagai boboan lakek atau dikenal dengan nama umum maman lanang. Tumbuhan Marsdenia brunoniana merupakan tumbuhan liar di pekarangan, bagian yang digunakan sebagai sayur bening adalah bagian daun. Masyarakat sempolan meyakini sayur daun belincong memiliki khasiat khusus untuk memperlancar produksi ASI. Informasi umum dari tumbuhan belincong belum banyak diketahui, disebutkan dalam penelitian Widodo, (2015) Marsdenia brunoniana (Gambar 3) merupakantumbuhan liar unik yang jenisnya sudah jarang diketahui di wilayah hunian penduduk. Dalam penelitian tersebut spesies ini ditemukan di pegunungan Baturagung, Yogyakarta dengan informasi sebaran di pulan jawa belum banyak dideskripsikan.

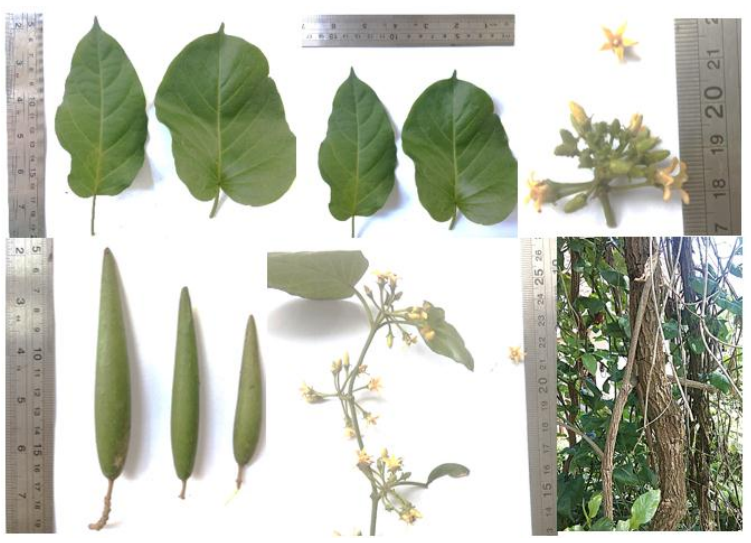

Gambar 3. Morfologi daun, bunga, buah dan batang Marsdenia brunoniana.

Jenis hidangan yang kedua adalah sayur kuah sedikit (tumis). Terdapat 9 spesies dimana dua diantaranya diolah sebagai sayur kuah banyak yaitu Gynandropsis gynandra dan Marsdenia brunoniana. Ketujuh spesies yang lain yaitu 1) Cnidoscolus aconitifolius tanaman perlu berkayu, tumbuh liar di tanah pekarangan. Bagian yang dimakan adalah daun (CABI, 2019); digunakan sebagai sayur serta bentuk olahan lain seperti jelly, rolade, dan rendang (Sudartini, Nur Arifah Qurota A'yunin,, \& Undang 2019). Limnocharis flava, Sphenoclea zeylanica, Monochoria vaginalis merupakan gulma tanaman padi, dan bagian yang ditumis berupa daun muda, dan bunga (CABI, 2019: 2020). Emilia sonchifolia bersifat liar di area persawahan, diolah sebagai tumis pada daun muda dan juga batang (Useful Tropical Plants, 2021). Solanum torvum tumbuhan perdu liar di area pekarangan. Bagian buah dimakan ditambahkan pada sup sebagai kari. Olahan Marsdenia brunoniana yang digunakan adalah buah yang dikenal dengan nama lokal "belincong". Tumbuhan liar dimanfaatkan sebagai tumis selanjutnya adalah dari kelompok Pteridophyta dikenal sebagai pakis (Diplazium esculentum). Dimasak dari bagian batang dan daun muda dari daerah jawa dan sumatera (Pawera et al., 2020; Umiyah, 2011).

Jenis olahan sayur dari tumbuhan liar yang ketiga adalah sebagai lalapan (stew vegetables) sebanyak 12 jenis tumbuhan diantaranya berupa tanaman perdu (Cnidoscolus 
aconitifolius, Solanum torvum); herba (Rorippa indica, Solanum ningrum, Crassocpehalum crepidioides, Emilia sonchifolia, Amaranthus spinosus, Ipomoea aquatica, Limnocharis flava, Monochoria vaginalis, Sphenoclea zeylanica) dan liana Marsdenia brunoniana. Beberapa diantaranya bisa digunakan sebagai olahan sayur kuah banyak dan tumis. Sebagai lalapan bagian daun dari Rorippa indica, Cnidoscolus aconitifolius, Solanum torvum Crassocpehalum crepidioides, Emilia sonchifolia, Amaranthus spinosus, Ipomoea aquatica, Limnocharis flava, Monochoria vaginalis, Sphenoclea zeylanica dikonsumsi dengan cara direbus dan kemudian dikonsumsi dengan sambal menjadi lalapan. Daun yang biasa direbus adalah daun muda, dengan sebagian batang muda dan juga bunga. Sedangkan lalapan dari buah yaitu dari spesies Marsdenia brunoniana dan Solanum ningrum. Rorippa indica tumbuh liar di areal persawahan sebagai gulma pada tanaman cabai (Sabri \& Ramadhani, 2018). Beberapa tumbuhan telah lama dibudiyakan dan komersil misalnya bayam, takokak, ranti, serta genjer.

Dua jenis oleahan sayur yang lain adalah urap dan pothok. Sayur urap merupakan jenis olahan sayur rebus dan kemudian ditambahkan dengan parutan kelapa yang telah dibumbu. Sedangkan pothok / botok adalah salah satu makanan khas Indonesia yang memiliki aroma khas karena adanya penambahan dari daun simbukan ( Pederia scansdens). Daun simbukan ditambahkan dengan bahan utama lainnya seperti parutan kelapa, teri, tempe, yang kemudian dibungkus daun pisang dan dimasak dengan cara dikukus.

Kelompok ke 3 adalah sebagai sumber buah. Terdapat 4 spesies yaitu 2 diantaranya berhabitus pohon yaitu Muntingia calabura ditemukan di pinggir jalan dan tanah pekarangan. Buah kersen masak berwarna merah dapat dikonsumsi secara langsung dan memiliki rasa yang manis, dapat digunakan sebagai olahan berupa selai (Laswati et al., 2017). Morinda citrifolia tumbuhan liar tumbuh di areal pekarangan. Buah yang dikonsumsi adalah buah mengkal mencapai matang, berwarna putih mengkilap, daging buah keras dan memiliki rasa pahit. Adapun cara konsumsinya adalah digunakan sebagai rujak buah yaitu buah dipotong-potong kemudian disiram gula jawa. Tumbuhan liar Morus sp. merupakan tumbuhan perdu berkayu, tumbuh liar di areal persawahan dan pinggir jalan. Buah berbentuk seperti anggur dengan citarasa kecut hingga manis. Buah masak berwarna merah dan merah kehitaman saat matang sempurna. Buah dapat dikonsumsi langsung maupun diolah menjadi minuman (Isnan \& Muin, 2015). Tumbuhan liar sebagai sumber buah segar selanjutnya adalah Physalis angulata. Tumbuh liar di areal persawahan sebagai gulma tanaman hortikultura. Bentuk buah bulat telur, berwarna kuning saat masak. Memiliki citarasa manis dengan tekstur daging buah lunak dan memiliki banyak biji (CCRC, 2008; Pawera et al., 2020).

\section{Kandungan Nutrisi Sumber Pangan dari Tumbuhan Liar}

Sumber karbohidrat, sayur dan buah diperlukan oleh tubuh secara berurutan sebagai sumber energi, sumber serat, vitamin dan mineral. Kandungan nutrisi dari masing-masing tumbuhan disajikan pada Tabel 1. Informasi nilai gizi dari 26 spesies tumbuhan liar yang digunakan sebagai sumber pangan di dusun plalangan Desa Sempolan berdasarkan referensi antara lain Buku Panduan untuk masyarakat: Keanekaragaman Hayati Lokal untuk Gizi dan Kesehatan Masyarakat (Pawera et al., 2020); Laman online Data Kemenkes TKPI (Tabel Komposisi Pangan Indonesia) (AndraFarm, 2019); serta komposisi fitokimia dari referensi tumbuhan liar sebagai obat ((Badrunasar \& Santoso, 2016; dan laman CCRC (Cancer Chemoprevention Research Center UGM) (2019) dan Useful Tropical Plant Database by Ken Fern (2021).

Dari keseluruhan bahan makanan tumbuhan liar semua diketahui bahwa tumbuhan memiliki kandungan nutrisi terdiri atas karbohidrat, protein, vitamin dan mineral. Karbohidrat merupakan zat gizi makro yaitu diperlukan tubuh dalam jumlah besar yaitu dalam satuan gram/orang/hari. Selain sebagai sumber energi, karbohidrat juga berfungsfi memberi rasa manis pada makanan. Bagian kedua dari zat gizi yaitu zat gizi mikro, diperlukan tubuh dalam jumlah yang kecil dalam satuan miligram/orang/hari. Contoh dari zat gizi mikro adalah berbagai jenis vitamin dan mineral.

Sayuran dan buah-buahan merupakan sumber vitamin, mineral, dan juga serat pangan. Kemenkes (2017) menyebutkan bahwa 
kebutuhan harian buah adalah $150 \mathrm{~g}$ / orang/ hari dan sayur $250 \mathrm{~g} /$ orang/ hari. Terdapat 13 jenis vitamin yang diperlukan tubuh yaitu vitamin A,C,D,E,K, dan B kompleks yang terdiri atas 8 jenis. Fungsinya vitamin di dalam tubuh sangat bervariasi antara lain sebagai koenzim, antioksidan, menjaga kesehatan mata, tulang, kulit, serta berperan dalam metabolisme sel. Mineral merupakan unsur anorganik, terlibat langsung dalam proses fisiologi tubuh sehingga harus selalu tersedia dalam makanan. Mineral makro diantaranya kalsium, sulfur, fosfor, magnesium, sedangkan minral mikro antara lain zat besi, seng, tembaga dan juga iodium (Atikah., Yulidasari., \& Setiawan : 2020). Konsumsi sayuran dan buah dapat memenuhi gizi seimbang kebutuhan tubuh, dan diketahui dapat menurunkan faktor resiko penyakit tidak menular kronik seperti darah tinggi, penyakit jantung, obesitas, diabeletes mellitus tipe 2 dan kanker (Pawera et al., 2020; Kemenkes: 2017).

Selain nilai gizi, tumbuhan juga memiliki kandungan senyawa bioaktif / fitokimia yang dapat berfungsi sebagai obat. Tumbuhan liar yang ditemukan sebagai sumber pangan pada penelitian ini, banyak diantaranya juga teridentifikasi digunakan sebagai tanaman obat seperti dalam buku misalnya Tumuhan liar berkhasiat obat (Badrunasar \& Santoso, 2016), dan laman seperti CCRC (Cancer Chemoprevention Research Center, UGM) yaitu sintrong, sawi tanah, semanggi, mengkudu, leunca, dan ciplukan. Selain itu, tanaman liar yang ditemukan juga berangsur-angsur menjadi tanaman yang dibudidayakan dan bernilai ekonomis seperti bayam, kangkung. Tersedianya tumbuhan liar yang bersifat alami, segar, gratis dan sangat bergizi dapat mendukung kesehatan masyarakat serta menjaga budaya dan warisan masyarkat.

\section{Kesimpulan}

Inventarisasi tumbuhan liar sebagai sumber pangan di Dusun Plalangan, Desa Sempolan, Kabupaten Jember menemukan 26 spesies dengan variasi habitus berupa herba, perdu, pohon dan liana. Tumbuhan liar yang teridentifikasi tumbuh secara liar maupun sebagai gulma pada tanaman hortikultura. Pemanfaatannya sebagai sumber pangan di masyarakat dapat melalui pengolalan menjadi hidangan tertentu maupun dikonsumsi secara langsung. Sebagai sumber karbohidrat, terdiri atas 4 spesies tanaman umbi berperan sebagai sumber energi. Rekomendasi pengolahannya adalah direbus, dijadikan keripik, kolak, dan tepung sebagai bahan kue. Pemanfaatan sebagai sayuran berasal dari 18 spesies dapat dari bagian batang, daun, bunga maupun buah. Olahan sayur masyarakat berupa sayur kuah banyak (sayur bening dan lodeh), sayur kuah sedikit (tumis), sebagai urap dan pothok. Buah segar didapatkan dari 4 spesies tanaman liar, dikonsumsi secara langsung dan juga sebagai bahan rujak. Kandungan nutrisi tumbuhan liar bervariasi meliputi vitamin, mineral makro dan mikro, serta fitokimia. Nutrisi tersebut penting untuk menjaga kesehatan masyarakat sekaligus dimanfaatkan sebagai obat.

\section{Ucapan terima kasih}

Ucapan terima kasih yang sebesarbesarnya disampaikan peneliti pada semua pihak yang telah membantu dalam proses penyelesaian penelitian, khususnya responden yaitu masyarakat Dusun Plangan Desa Sempolan, Silo Jember. 
Kuswati \& Widi Cahya Adi (2021). Jurnal Biologi Tropis, 21 (2): 393 - 402

DOI: http://dx.doi.org/10.29303/jbt.v21i2.2607

Tabel 1. Keragaman Jenis Tumbuhan Liar sebagai Sumber Pangan

\begin{tabular}{|c|c|c|c|c|c|c|c|}
\hline \multirow[t]{2}{*}{ No } & \multicolumn{3}{|c|}{ Name } & \multirow{2}{*}{ Famili } & \multirow{2}{*}{ Preferensi Penyajian } & \multirow{2}{*}{$\begin{array}{l}\text { Bagian yang } \\
\text { Dikonsumsi }\end{array}$} & \multirow[b]{2}{*}{ Kandungan Nutrisi } \\
\hline & Nama Lokal & Nama umum & Spesies & & & & \\
\hline 1 & 2 & 3 & 4 & 5 & 6 & 7 & 8 \\
\hline \multicolumn{8}{|c|}{ Sumber Karbohidrat } \\
\hline 1 & Obih & Uwi & Dioscorea alata & Dioscoreaceae & $\begin{array}{l}\text { Makanan samping / } \\
\text { Camilan }\end{array}$ & Umbi & Karbohidrat, Natrium, Kalium \\
\hline 2 & Geddhung & Gadung & Dioscorea hispida & Dioscoreaceae & $\begin{array}{l}\text { Makanan samping / } \\
\text { Camilan; Keripik }\end{array}$ & Umbi & Karbohidrat, Kalium \\
\hline 3 & Logsor & Garut & Maranta arundinacea & Marantaceae & $\begin{array}{l}\text { Makanan samping / } \\
\text { Camilan; Tepung }\end{array}$ & Umbi & $\begin{array}{l}\text { Karbohidrat, Fosfor, } \\
\text { Magnesium, Vitamin A }\end{array}$ \\
\hline 4 & Ganyong & Ganyong & Canna edulis & Cannaceae & $\begin{array}{l}\text { Makanan samping / } \\
\text { Camilan; Tepung }\end{array}$ & Umbi & Karbohidrat, Fosfor \\
\hline \multicolumn{8}{|c|}{ Sayuran } \\
\hline 1 & Kajuh neymor & Kastuba & Euphorbia pulcherrima & Euphorbiaceae & Sayur Bening & Daun & $\begin{array}{l}\text { Vitamin C, Zink, Kalsium, } \\
\text { Zat Besi }\end{array}$ \\
\hline 2 & Tes-katesan & Pepaya jepang & $\begin{array}{l}\text { Cnidoscolus } \\
\text { aconitifolius }\end{array}$ & Euphorbiaceae & Lalapan, Tumis & Daun, Bunga & $\begin{array}{l}\text { Protein, Kalsium, zat besi, } \\
\text { Vitamin A, Vitamin C }\end{array}$ \\
\hline 3 & Boboan Lakek & Mamam ungu & Cleome rutidospermae & Capparaceae & Tumis, Sayur Bening & Daun, Bunga & $\begin{array}{l}\text { Vitamin A, Kalium, Kalsium, } \\
\text { Vitamin C }\end{array}$ \\
\hline 4 & Boboan & - & $\begin{array}{l}\text { Gynandropsis } \\
\text { gynandra }\end{array}$ & Capparaceae & $\begin{array}{l}\text { Tumis, Sayur Bening, } \\
\text { Lodeh }\end{array}$ & Daun, Bunga & $\begin{array}{l}\text { Vitamin A, Vitamin E, } \\
\text { Vitamin C }\end{array}$ \\
\hline 5 & Pokak & Takokak & Solanum torvum & Solanaceae & Lalapan, Tumis & Buah & $\begin{array}{l}\text { Saponin, Tanin. Flavonoid, } \\
\text { Lemak, Kalsium, Kalsium, } \\
\text { Fosfor, Zat Besi, Vitamin A, } \\
\text { B dan C. }\end{array}$ \\
\hline 6 & Ranteh & Ranti & Solanum ningrum & Solanaceae & Lalapan & Daun, Bunga, Buah & $\begin{array}{l}\text { Vitamin C, Vitamin A, Zat } \\
\text { Besi, Kalsium, Fosfor }\end{array}$ \\
\hline 7 & Jonggolan & Sintrong & $\begin{array}{l}\text { Crassocpehalum } \\
\text { crepidioides }\end{array}$ & Asteraceae & Lalapan & Batang, Daun, Bunga & Zat besi, Fosfor. \\
\hline 8 & Be’sarap & Kemondelan & Emilia sonchifolia & Asteraceae & Tumis, Lalapan & Batang, Daun, Bunga & $\begin{array}{l}\text { Kalsium, Kalium, Natrium, } \\
\text { Magnesium, Mangan, Zat } \\
\text { besi, Tembaga. }\end{array}$ \\
\hline 9 & Belincong & - & Marsdenia brunoniana & Apocynaceae & $\begin{array}{l}\text { Lalapan, Tumis, Sayur } \\
\text { Bening }\end{array}$ & Daun. Buah & Tidak Tersedia \\
\hline
\end{tabular}


Kuswati \& Widi Cahya Adi (2021). Jurnal Biologi Tropis, 21 (2): 393 - 402 DOI: http://dx.doi.org/10.29303/jbt.v21i2.2607

\begin{tabular}{|c|c|c|c|c|c|c|c|}
\hline \multirow[t]{2}{*}{ No } & \multicolumn{3}{|c|}{ Name } & \multirow{2}{*}{ Famili } & \multirow{2}{*}{ Preferensi Penyajian } & \multirow{2}{*}{$\begin{array}{l}\text { Bagian yang } \\
\text { Dikonsumsi }\end{array}$} & \multirow{2}{*}{ Kandungan Nutrisi } \\
\hline & Nama Lokal & Nama umum & Spesies & & & & \\
\hline 1 & 2 & 3 & 4 & 5 & 6 & 7 & 8 \\
\hline 10 & Bejem & Bayam & Amaranthus spinosus & Amaranthaceae & $\begin{array}{l}\text { Sayur bening, Lalapan, } \\
\text { Keripik }\end{array}$ & Daun & $\begin{array}{l}\text { Zat Besi, Asam Folat, } \\
\text { Vitamin A Viamin K, } \\
\text { Vitamin E }\end{array}$ \\
\hline 11 & Da'-selada'an & Sawi tanah & Rorippa indica & Brassicaceae & Lalapan & Daun, Bunga & $\begin{array}{l}\text { Kalsium, Magnesium, Fosfor, } \\
\text { Zat Besi }\end{array}$ \\
\hline 12 & Kangkong & Kangkung air & Ipomoea aquatica & Convolvulaceae & Tumis, Lalapan & Batang, Daun & $\begin{array}{l}\text { Fosfor, Magnesium, Vitamin } \\
\text { C, Vitamin A, Kalium, } \\
\text { Kalsium, Magnesium, dan Zat } \\
\text { besi }\end{array}$ \\
\hline 13 & Semanggi & Semanggi & Oxalis corniculata & Oxalidaceae & Sayur Bening & Daun & Vitamin A, Zat Besi \\
\hline 14 & Tong-centhongan & Genjer & Limnocharis flava & Limnocharitaceae & Tumis, Lalapan, Urap & Batang, Daun, Bunga & $\begin{array}{l}\text { Vitamin C, Vitamin A, Zat } \\
\text { Besi, Kalsium, Fosfor }\end{array}$ \\
\hline 15 & Pakes & Pakis & Diplazium esculentum & Polypodiaceae & Tumis, Urap & Batang, Daun & $\begin{array}{l}\text { Vitamin A, Zat Besi dan } \\
\text { Kalsium }\end{array}$ \\
\hline 16 & Re'- bire'an & Eceng & Monochoria vaginalis & Pontederiaceae & Lalapan, Tumis & Batang, Daun, Bunga & $\begin{array}{l}\text { Fosfor, Kalium, Magnesium, } \\
\text { Mangan, Kalsium. }\end{array}$ \\
\hline 17 & Kasembukhan & Simbukan & Paederia foetida & Rubiaceae & Pothok & Batang, Bunga & $\begin{array}{l}\text { Kalsium, Natrium, Kalium, } \\
\text { Zat Besi, Vitamin C. }\end{array}$ \\
\hline 18 & Gundhe' & Gunda & Sphenoclea zeylanica & Sphenocleaceae & Tumis, Lalapan & Batang, Daun, Bunga & $\begin{array}{l}\text { Vitamin A, Vitamin C, Zat } \\
\text { Besi, Kalsium }\end{array}$ \\
\hline \multicolumn{8}{|c|}{ Buah Segar } \\
\hline 1 & Arbei & Murbai & Morus alba & Moraceae & Segar & Buah & $\begin{array}{l}\text { Asam Lemak, Magnesium, } \\
\text { Kalium, Kalsium, Fosfor }\end{array}$ \\
\hline 2 & Kersen & Kersen & Muntingia calabura & Muntingiaceae & Segar & Buah & Kalsium, Fosfor, Vitamin C \\
\hline 3 & Koddu’ & Mengkudu & Morinda citrifolia & Rubiaceae & Segar & Buah & Vitamin C, Kalsium \\
\hline 4 & Or - nyioran & Ciplukan & Physalis angulata & Solanaceae & Segar & Buah & $\begin{array}{l}\text { Vitamin C, Vitamin A, Zat } \\
\text { besi }\end{array}$ \\
\hline
\end{tabular}




\section{Referensi}

Andra Farm (2019). Tabel Komposisi Pangan Indonesia. Bogor: Jawa Barat. https://www.andrafarm.com/_andra.php? i=daftar-tkpi (Diakses tanggal 10 Februari 2021)

Atika, R., Yulidasari, F., \& Setiawan, M.I. (2020). Dasar-dasar Gizi. CV Mine: Yogyakarta. ISBN 9786237550419. Pp 200.

http://eprints.ulm.ac.id/10046/1/BUKU\% 20AJAR\%20DDG.pdf

Badrunasar, A., \& Santoso, H. B. (2016). Tumbuhan Liar Berkhasiat Obat (E. Rachman \& M. Siarudin (eds.)). Forda Press: NTB. ISBN: 9786026961150. pp 184. http://balitbangtekhhbk.org/2019/12/unggah/filepublikasi/Digital-BUKUGULMA_OBAT.pdf

CABI (2021). Invasisive Species Compendium. Wallingford, UK: CAB International. https://www.cabi.org/isc/datasheet

(Diakses pada tanggal 10 Februari 2021)

CCRC (Cancer Chemopreventuon Reasearch Center) (2021).

UGM. https://ccrc.farmasi.ugm.ac.id/ (Diakses pada tanggal 20 Februari 2021).

Destryana, A., \& Ismawati (2019). Etnobotani Dan Pengggunaan Tumbuhan Liar Sebagai Obat Tradisional Oleh Masyarakat Suku Madura. Journal of Food Technology and Agroindustry, $\quad 1(2), \quad 1-8$. https://doi.org/10.24929/jfta.v1i2.724

Diba, F., Sholihin, M., \& Nurhaida, N. (2021). Utilization of plants as food source from Sebaju village forest, Nanga Kebebu village, Nanga Pinoh District, Melawi Regency. Jurnal Biologi Tropis, 21(1), 52. https://doi.org/10.29303/jbt.v21i1.2317

Furkon, L.A. (2021). Modul 1. Mengenal Zat Gizi. http://repository.ut.ac.id/4335/2/PEBI4424 -M1.pdf (Diakses pada tanggal 20 Februari
2021)

Handayani, T. H. W., \& Marwanti. (2011). Pengolahan Makanan Indonesia. Yogyakarta: Universitas Negeri Yogyakarta. pp 94. http://staffnew.uny.ac.id/upload/13230010 5/pengabdian/modul-ppg-pengolahanmakanan-indonesia.pdf

Herison, C.,Turmudi, E., \& Handajaningsih, M. (2010). Studi Kekerabatan Genetik Aksesi Uwi ( Dioscorea sp ) yang dikoleksi dari Beberapa Daerah di Pulau Jawa dan Sumatera. Akta Agrosia, 13(1), 55-61. http://repository.unib.ac.id/75/1/Akta\%201 3\%281\%29_55-61.pdf

Isnan, W., \& Muin, N. (2015). Tanaman Murbei : Sumber Hutan MultiManfaat. Info Teknis Eboni, Vol. 12(2), 111-119. https://doi.org/10.20886/buleboni.5062

Kemenkes (2017). Ayo Makan Sayur dan Buah Setiap Hari. https://www.kemkes.go.id/article/view/170 12600002/hari-gizi-nasional-2017-ayomakan-sayur-dan-buah-setiaphari.html\#: :text=Bag (Diakses pada tanggal 20 Februari 2021)

Key Fern (2019). Useful Tropical Plants Databse. http://tropical.theferns.info/ (Diakses pada tanggal 17 Februari 2021)

Khan, F. A., Bhat, S. A., \& Narayan, S. (2017). Wild edible plants as a food Resource: Traditional Knowledge. University of Agricultural Science and Technology, Research Gate, March. https://doi.org/10.13140/RG.2.2.34547.53 285

Laswati, D. T., Sundari, N. R. I., \& Anggraini, O. (2017). Pemanfaatan Kersen (Muntingia calabura L) Sebagai Alternatif Produk Olahan Pangan: Sifat Kimia Dan Sensoris. Jurnal JITIPARI, 4(2), 127-134. http://dx.doi.org/10.33061/jitipari.v2i2.189 9

Nurlaha, N., Setiana, A., \& Asminaya, N. S. 
(2014). Identifikasi Jenis Hijauan Makanan Ternak Di Lahan Persawahan Desa Babakan Kecamatan Dramaga Kabupaten Bogor. JITRO, l(1), 54. https://doi.org/10.33772/jitro.v1i1.361

Ogle, B. M. (2001). Wild Vegetables and Micronutrient Nutrition. Studies on the significance of wild vegetables in women's diets in Vietnam. Sweden: Uppsala University. ISBN 9155450687. pp 55. http://www.diva-

portal.org/smash/get/diva2:168542/FULL TEXT01.pdf

Liza, L., Oramahi, H. A., \& Sisillia, L. (2020). Jenis tumbuhan yang dimanfaatkan sebagai Sumber Pangan Oleh Masyarakat Desa Jawai LLaut Kecamatan Jawai Selamatan Kabupaten Sambas. Jurnal Hutan Lestari, $8(2$, $315-324$. http://dx.doi.org/10.26418/jhl.v8i2.40052

Pawera, L., Lipoeto, N. I., Khomsan, A., \& Zuhud, E. A. M. (2020). Buku Panduan untuk Masyarakat: Keanekaragaman Hayati Lokal untuk Gizi dan Kesehatan Masyarakat. $\quad 156$ https://sipakaril.ipb.ac.id/Files/0f24e8e8$8 \mathrm{~d} 2 \mathrm{e}-4 \mathrm{c} 46-\mathrm{b} 057-$ e888011c36c5/paper_0f24e8e8-8d2e4c46-b057-e888011c36c5.pdf

Sabri, Y., \& Ramadhani, R. (2018). Jenis-jenis Gulma di Sekitar Pertanaman Cabai sebagai Tumbuhan Inang Trips (thysanoptera: Thripidae) di Nagari Pakan Sinayan Kec. Banuhampu Kabupaten Agam. Jurnal Pertanian UMSB, 2(1), 52-59. https://doi.org/10.33559/pertanian\%20ums b.v2i1.1152

Sembori, F., \& Tanjung, R. (2009). Inventarisasi Jenis Tumbuhan Pangan Lokal pada Masyarakat Ambaidiru Distrik Kosiwo, Kabupaten Yapen Waropen. Jurnal Biologi Papua, 1(April), 36-41. https://doi.org/10.31957/jbp.570

Sholichah, L., \& Alfidhdhoh, D. (2020). Ethnobotany of the Wild Plant as a Food Crop in Mendiro Village, Wonosalam
District, Jombang. Jurnal Ilmu Pertanian Indonesia, 25(1), 111-117. https://doi.org/10.18343/jipi.25.1.111

Soetiarso, T. (BALITSA) (2010). Sayuran Indigenous alternatif sumber pangan bernilai gizi tinggi. Iptek Hortikultura, 6(Agustus), 5-10. http://hortikultura.litbang.pertanian.go.id/I PTEK/Soetiarso_indigenous.pdf

Sudartini, T., Nur Arifah Qurota A'yunin, Undang (2019). Karakterisasi nilai gizi daun chaya ( cnidoscolus chayamansa) sebagai sayuran hijau yang mudah dibudidayakan. Media Pertanian, 4(1), 3039.

http://jurnal.unsil.ac.id/index.php/medpert anian/article/view/1356

Trustinah (2013). Karakteristik Dan Keragaman Morfologi Uwi-Uwian ( Dioscorea sp .). Prosiding Seminar Hasil Penelitian Tanaman Aneka Kacang dan Umbi, 717726.

http://balitkabi.litbang.pertanian.go.id/wpcontent/uploads/2017/02/prosiding_2013_ 6_1.pdf

Umiyah (2011). Pemanfaatan Beberapa Tumbuhan Liar ( Gulma ). Berk. Penel. Hayati, 17(2005), 103-107. http://dx.doi.org/10.23869/bphjbr.17.1.201 120

Widodo (2015). Apocynoideae dan Asclepiadoideae dari Pegunungan Baturagung ( Gunung Nglanggeran , Gunung Mintorogo, Gunung Parangan, Gunung Gedang, Gunung Ijo ): Inisiasi Pencirian dan Konservasi. Seminar Nasional Konservasi dan Pemnfaatn Sumber Daya Alam, 1(1), 74-85. https://jurnal.fkip.uns.ac.id/index.php/kpsd a/article/view/5352 